ISSN:

Print - $2277-078 \mathrm{X}$

Online - $2315-747 \mathrm{X}$

(c) FUNAAB 2016

\title{
AN ANALYSIS OF YIELDS OF KOLA-N UT PRODUCTION, PROCESSING AND MARKETING IN SAGAMU LGA, OGUN STATE, NIGERIA
}

\author{
E. O. A. OLUWALANA, , L. O. O KOJIE, F. O ASH AOLU AND V. O.OLANIRAN
}

D epartment of Agricultural Economics and Farm Management, Federal University of Agriculture, Abeokuta

Comesponding Author: oluwalanaeoa@ funaab.edu.ng Tel.: +2348037158122

\begin{abstract}
ABST RACT
This study on Kola nut production in Ogun State was aimed at describing the socio-economic characteristics of the farmers, net farm income, marketing channels and factors influencing output of kola nut for its impact on food security. Multistage sampling technique was used in the study; the first stage involves the purposive selection of Sagamu Local Government as largest Kola nut farming with 4 communities; namely; Agbowa; Sagamu; Igodo, and Odelemo. The second stage involves simple random selection of 100 kola nut farmers, 25 per community. A structured questionnaire was administered subject to descriptive analysis, multiple regressions, and budgetary analysis. The results revealed that male $82 \%$ and female $18 \%$ were involved in kola nut production, processing and marketing. Average household size of 6 members with a minimum of 25 years farming experiences. The study revealed that $51 \%$ of the farmers sold directly to wholesalers, $37 \%$ sold to processors, and $12 \%$ sold to retailers. Also, $83 \%$, of the producers and marketers were married $16 \%$ were widowed and only $1 \%$ divorced. Average age was 58years and average farm size of 2.71 hectares. Average farm net income was $\$ 208,680.40$ per annum with the total revenue of $\$ 291,149$ and a gross margin of $\$ 237,789.50$ per annum. The average total cost incurred was calculated as $\$ 82,468.40$ being cost of labour, transportation and items such as cutlass, hoes and files.
\end{abstract}

Regression analysis used to determine the factors affecting the output of kola nut showed that farm size, age of kola nut plantation and the age of farmers were significant at $10 \%, 5 \%$ and $1 \%$ respectively using double log equation and the model was significant at $1 \%$. The age of farmers $\left(x_{1}\right)$ was negatively significant which implies that as farmers reach old age, this may serve as hindrance due to physical inability to undertake vigorous farm activities hence reduction in output occurs by $13.3 \%$. Farming experience $\left(\mathrm{x}_{2}\right)$ was negatively correlated with output of kolanut indicating that a unit increase in experience of kolanut farmers will decrease output by $12.3 \%$. Farm size was found to positively significant which implies that a unit increase in farm size will increase output by $83.1 \%$.

The result revealed that kola nut business is a profitable venture and male dominated. The women could be encouraged to invest in the business to increase their income and livelihood.

Keywords. Kolanut production, processing, marketing, enterprise, Food Security.

INTRODUCTION

Agriculture is an important sector of the economy in Nigeria; more than $70 \%$ of the populations are engaged in agriculture either directly or indirectly. The country's agricultural products fall into two major groups; 


\section{E. O. A. OLUWALANA, , L. O. O KOJIE, F. O ASHAOLU AND V. O .O LANIRAN}

food crops and cash crops. Kola nut however, belongs to cash crops. Kola nut is the fruit of the Kola tree; a genus of trees native to the tropical rainforest of Africa. It has been introduced to other tropical countries like Gabon, West India and Brazil. Six species of Kola nut can be found in West Africa and the popular ones are kola Nitida and Acumilata. They are second in importance as a commercial crop to Cocoa in the Southern part of Nigeria (Adejompo, 2014).

Kola nut is used as a masticatory stimulant by Africans and has numerous uses in social, religious, ritual, and ceremonial functions by the natives in the forest region of Africa (Asogwa \& al., 2006). It is used during ceremonies related to marriage, child naming, installation of Chiefs, funeral, and sacrifices made to the various gods of African mythology (D aramola 1978 and O peke, 1992). There is also increasing demand for its usage in pharmaceutical industries and for production of soft drinks, wines, and candles (Beattie, 1970 and O gunuga, 1975). Its uses have inevitably created a high de- mand in excess of its production (Oladokun, 1985). Kola nuts are widely cultivated in $\mathrm{Ni}$ geria. Large quantities of the nuts are exported to Europe and North America, where they are used chiefly for flavouring cola drinks such as Coca-Cola, which are refreshing or stimulating substitutes for tea or coffee (Irvine, 1956). Beverages such as kola wine, kola cocoa and kola chocolate-a type of chocolate containing cacao and kola powder in cocoa butterfat (Opeke, 1992) - and one interesting sounding concoction called "Burroughs and Wellcomes Forced March Tabloid" were once tried in Britain, but they were short lived (Tindall, 1998).

Kola nuts also have medicinal values, sociocultural values and uses.

Kola nut tree is sacred and its sacredness is used in divinity as it can explain the oracle. It is an evergreen tree, the genus include about forty species. It has glossy green leaves, violet stripped flowers and star-shaped fruits. The seeds are taken from the pod as their outer coat or cover is removed. They are chewed while fresh or dried.

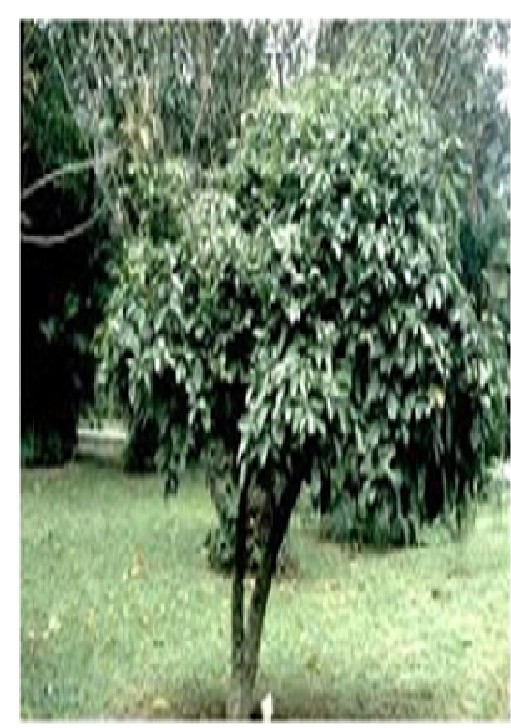

TolanuIres

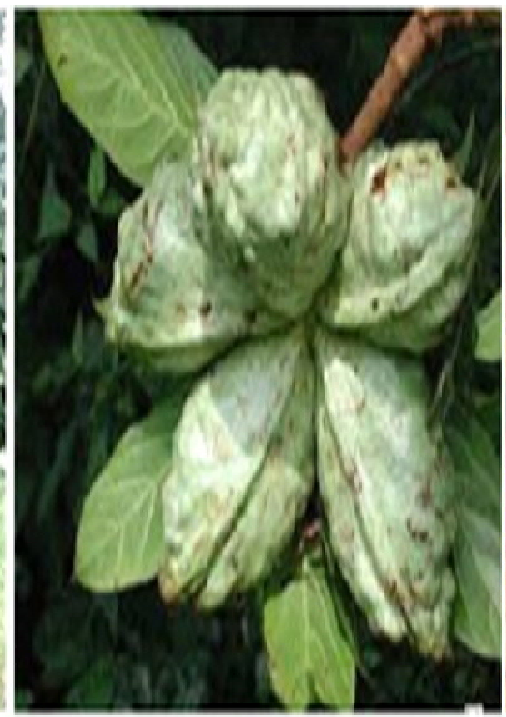

Chpocessed Idenut

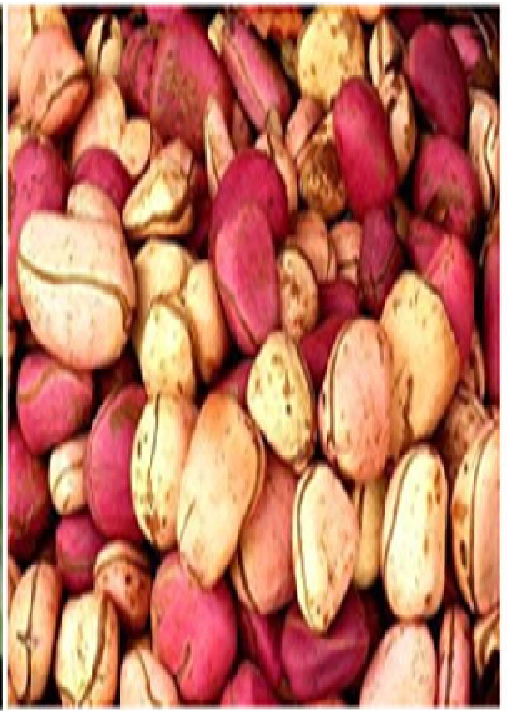

Proxsed Kolanut 
However, Ndagi, \& al., (2012) reported some of the Challenges of kola nut production to be low yield, lack of information on improved technology, pest and disease infestation, lack of intervention from the government, and transportation. Farmers still hold kola nut production in high esteem, and there is vast area of land which could be used for kola nut production.

Adejompo (2012) study reveals a significant positive impact of kola nut production on employment creation, poverty alleviation, industrial development and socio-cultural values. It also reveals kola nut as an important stimulant and a source of feed to animals.

In a period of global economic recession, Kola nut production is germane for socioeconomic revival, revamping and rejuvenation. The paper further posits that kola nut production if encouraged will have a multiplier effect, serving as a liberator from unemployment quagmire, which is one of the bane and major clog in the wheel of development, especially in the African continent.

In the light of this, the survey investigates among others the factors influencing the input yield in kola nut production, processing and marketing in Ogun State as well determine the net farm income of kola nut production as profitable venture in Ogun State.

\section{Statement of Problem}

The advent of oil boom in the country in the mid 1970s resulted in the neglect of the agricultural sector with the government contributing little to nothing to the sector with decline in the GDP generated through agriculture from 56\% between 1960 and 1969 to an average of $24 \%$ between 1970 and $1979,22 \%$ in 1980 and a fluctuation between 16\% and 24\% between 1981 and 1985 (CBN/ NISER, 1992). The trend in decline still continues till present as the bulk of the agricultural products consumed in the country are imported with little coming from the subsistence system of farming majorly practiced in the country. Also, Alademerin and O dusina (2009) in Makinde \& al., (2013) reported that as Nigerian economy fortunes have turned in cycle, much attention is being paid to rehabilitation of estate plantation and the development of new ones, and that most estates plantations are being put up for outright sale or long management lease to private investors/ enterprises.

This neglect culminates into scarcity of kola nut in the market as the production and supply has been inadequate. Considering this fact, there is no doubt that the potential uses and importance of kola nut can be both a saver and earner of considerable foreign exchange for Nigeria, more income for kola nut farmers and employment for the Nigeria youths.

Invariably, Ogun state produces the largest amount of Kola nut in the country devoting about 65,000 hectares of land and producing 80,000 MT of the crop in 2010/2011 (National survey on Agricultural Exportable commodities,2013). More so, the production of Kola nut is influenced by soil fertility and the ability of any soil to replace nutrients absorbed by crops depend mainly on the clay type, mineral composition of the fine fraction and soil fraction in topo sequence. Aiboni and Ogunkunle (1988) have shown that the presence of weather able minerals in the fine sand fraction within $200 \mathrm{~cm}$ of the profile is one of the conditions for high fertility of tropical soils. 


\section{E. O. A. OLUWALANA, , L. O. O KOJIE, F. O ASHAOLU AND V. O .OLANIRAN}

\section{Kola nut Utilization and Importance in Nigeria \\ Local/ Traditional Uses}

Kola nut has so many uses ranging from medical, social and religious aspects of human existence. It is majorly masticated (chewed) by the people of Nigeria because they are thought to act as stimulant and anti -depressant, reduce fatigue and hunger, aid digestion and work as an aphrodisiac and confers clear mindedness at work (Oladokun, 2000). It is a very important fruit among the three ethnic groups in $\mathrm{Ni}$ geria (Hausa, Ibo and Yoruba) as it serves values like peacemaking, friendship and sympathy. The three ethnic groups use kola nut in a similar fashion although the Hausa part of the country consumes more kola than other parts of the country while the Ibos attach more spiritual(mythological) and symbolic use to kola nut. Kola nut is used in naming ceremonies for symbolic reasons and other celebrations. It is often offered to show hospitality and as a symbol of appreciation among the Yoruba's and Ibo also the Hausa tribe uses it to invite friends to ceremonies and as a sign of seriousness to show their interest in a lady. They present the family of the lady a number of baskets of kola nut and the family in turn refuses offer from other suitors temporarily until she is married off to the man). Kola is also a source of ingredient for cloth dying.

\section{Industrial Uses}

A publication from Obeng and Brown, (2001) gave some of the utilization of kola nut as;

1. Liquid Detergent: The kola-pod ashbased liquid detergent is a proven product that has attracted wide patronage. Large quantities were produced on contract by the Directorate for Food and
Rural Infrastructure (D FFRI) during the military regime in Nigeria. Later, the Ministry of Defense also entered into a contract with CRIN for production in large quantities. The liquid detergent, which foams very well, continues to attract attention at Trade Fairs, Exhibitions, etc. It is a valuable product in the kitchen for washing utensils, and few drops of it are needed for cleansing.

2. Organic Fertilizer: The kola-pod huskbased organic fertilizer has been proven on our experimental station. It is simple and will be easily understood by our peasant farmers who operate at small- and mediumscale levels. According to Olubamiwa (2002), this product will be of advantage in kola-producing areas in view of present procurement logistic problems of inorganic fertilizers, worldwide demand for organic fertilizer and the low organic matter content in our soils.

\section{Poultry feed (Layers and Broilers}

Mash): The use of kola-pod husk in layers mash was first tested by CRIN in 1998. It was a novel trial, being the first of its kind in the world. The result was rather interesting; KPH suitably and economically replaced $60 \%$ of the maize in a conventional layers mash. It was concluded that there is need to test the reproducibility of the result. This was confirmed on-farm at a poultry farm in Imota, Lagos State. In the later trial, 10 and 15 percent dietary inclusions of KPH reduced feed cost while not sacrificing bird performance (Olubamiwa $\notin$ al., 2002). Babatunde and Hamzat (2005) also said inclusion of kola pod husks brings about increased growth and productivity of broilers.

4. Snail Feed: Trials by CRIN have shown that sole or partial feeding of kola testa 
(KOLA-T) to snails under a kolanut plantation is a worthwhile, commercially viable, venture. Raising snails under kola plantation will ensure sustainability of kolanut production because the kola farmer ploughs waste into snails in a sustainable fashion. It will also ensure soil enrichment through excreta of the snails cohabiting in the plantation and additional income for the farmer who may not need to wait till the kolanut harvest season before he can earn an income from his plantation. Feeding KOLA$\mathrm{T}$ solely to snails was found to be better than other common snail feedstuffs.

5. Kola Wine: The recipe for Kola wine has been perfected by Ogutuga, (1975). CRIN recently evolved another recipe which is highly relished by a cross-section of those who have patronized it. The cost of production is about half the market price of this wine (O lubamiwa $\notin \mathrm{al}$. 2002).

Opeke, 2005 also gave other industrial uses of kola as;

- Used for beverage making i.e. choco -cola a beverage that contains extracts of cocoa and kola

- Used as a source of alkaloids, caffeine and theobromine for pharmaceuticals

- Used as a source of essential oils for flavorings in confectionary industries

\section{Medicinal Uses}

Obeng and Brown, 2001 gave some of the medical uses of kola as;

1. Used as digestive aid prior to meals to stimulate gastric juice and bile production

2. Caffeine and the bromine; makes kola a potent neuro-stimulant that is used to combat fatigue
3. The kola nut and its extracts have been used to successfully treat respiratory conditions such as asthma and whooping cough as the caffeine, theobromine and teophylline contents act as vasodilators that dilate the blood vessels, allowing for greater circulation of oxygen.

4. It is also used to treat toothache, diarrhea, exhaustion, headaches, hunger (caffeine content makes it an effective appetite suppressant), malaria, nausea, poison antidote, tonic and stimulant.

\section{Composition of Kolanut}

Kolanut contains all these constituents; $13 . \%$ water, $9.5 \%$ crude protein, $1.4 \%$ fat, $7 \%$ cellulose, 3.8\% tannin, 2.8\% caffeine, $0.05 \%$ theobromine and 3\% ash(Purseglove,1968). Other constituent of kolanut are Phenolics, $d$ -catechin, I-epicatechin, kolatin, kolanin, betaine, Phlobaphens and the antocyanin pigment kola red.

\section{Diseases of Kolanut}

The kola trees are hosts to many field and post harvest diseases such as brown spot, brown blight, brown root rot and tip blight diseases. The brown spot disease manifests itself through chlorotic spots, which latter becomes dark brown with chlorotic surroundings. The causal agent is Pestalctia spp The heavily infected leaves become dry and latter fall off (Adebayo, 1966). The casual organism for brown blight is Bdryodiploda thedbramae. It forms small spots of irregular brown discolouration on the leaves, which later become enlarged and cause the leaves to assume a blight appearance. The brown root rot caused by Amillania mellea and Fomes moxius causes extensive root decay of kola trees in the field (Odebode and Olunloyo, 1989). The tip blight disease caused by Pho mopsis spp results in the blackening of young kola leaves tips and their subsequent death at 
a very tender stage (Odebode and $\mathrm{Ol}$ unloyo, 1989).The major fungal Muror spp and Fusaniumspp which are all known to be favoured by high relative humidity (Adebayo, 1966; Olunloyo, 1979; Agbeniyi and Fawole, 1999; Agbeniyi \&al., 2000).

\section{Marketing of Kola-nut in Nigeria}

According to O kesina (1989) sourcing of kola nut is not only dependent on the availability in a locality but also to a great extent on the distance of the source to the traders' location which is a function of transportation cost. It is also due to variability in prices even at different locations in a geographical area. He goes on to state that purchasing methods of kola nut are peculiar to each type of kola nuts whether processed or unprocessed. The features used to determine the quality of unprocessed kola nuts are random picking insect appearance in the lots of the nuts, sizes e.t.c. For processed kola nuts, the criteria used colour, sizes extent of damage, extent of storage e.t.c. Nigerian kola nut market has three main components; The Local tier, the interregional tier and the international tier as identified by Akinbode (1982). The market tiers represent the movement of kola nut from the producer through some set of individuals till it gets to the final consumer. It is observed that the Hausas are heavily involved in the marketing of kola nut in Nigeria and this is backed up by Okesina (1982) who opined that both the local and interregional tiers are dominated by the Hausas.

\section{The Local Tier}

This comprises the individuals such as local women and Hausa middlemen who buy and assemble kola nuts from villages and farms throughout to the producing areas. The local women often serve as processors as they process, store and sell them to towns and villages around the producing area. However, bulk of the kola nut assembled is sold to Hausa kola nut agents or middlemen who transport them to the North for further marketing or consumption.

\section{The Inter- Regional Tier}

This tier is believed to be backed up by wealthy Hausa individuals in various parts of the Northern states. The tier is considered to be the most important in kola nut marketing in Nigeria as it is estimated to take $80 \%$ of the total marketing while the local and international accounts for just 20\% (Akinbode, 1982). This is attributed majorly to the importance of kola nut in the Hausa culture and much more because the of the low capital base of the southem traders.

The International Tier: This takes care of demands outside the country and it involves only a few thousand tones of kola nuts.

\section{Marketing Channels of Kolanut}

Marketing channel refers to the route taken by a product from the producer until it gets to the final consumer. It also entails the path of a commodity from its raw form to the finished form as it moves from the producer to the final consumer.

The marketing channels for agricultural products vary from product to product, country to country and even from one locality to another. There are two types of marketing channel namely;

- Centralized channel: refers to a channel where the products are first assembled in a large central, terminal or producer market by commission agents or brokers who act as farmers' agents before being purchased by processors, retailers or wholesalers.

- Decentralized channel: channel 
where the processors and wholesalers purchase directly from the farmers. The marketing channel for agricultural product in Nigeria is mainly decentralized.

The important channels of distribution are; Producer/ Manufacturer $\rightarrow$ Consumer Producer/ Manufacturer $\rightarrow$ Retailer $\rightarrow$ Consumer

Producer/ Manufacturer $\downarrow$ Wholesaler

$\rightarrow$ Retailer $\rightarrow$ Consumer

Producer/ Manufacture $\rightarrow \quad$ Commission Agents $\longrightarrow$ Consumer

\section{METHODOLOGY}

\section{Study Area}

The Local government by virtue of its geographical location lies within the tropics. Its coordinates are 6051' $0^{\prime} \mathrm{N}$ and $3039^{\prime} 0^{\prime} \mathrm{E}$ in Degrees Minutes Seconds (DMS) or 6.85 and 3.65 in decimal degrees. It is bounded in the East by Ikenne Local G overnment, in the North by Remo Local Government, in west and south by Obafemi Owode Local Government of Ogun State and Ikorodu Local G overnment of Lagos State.

Sagamu Local G overnment in its geographical and political administrative extension spans a total area of 68.3 square kilometers. The climate pattern of the Local Government is a subset of humid tropical region, characterized by relative high temperature, apparent absence of cold session, low pressure and high relative humidity. As at 2006 population census figure, Sagamu Local Government area has a total population figure of 253,421 people.

\section{Data collection and Sampling}

The data used in this study was collected through personal interview and a close- ended questionnaire administration to kola nut farmers in Sagamu Local Government area of Ogun State. Field trips were also made to complement the information garnered through the questionnaires. Multistage sampling procedure was adopted in this study, where the first stage involves the purposive selection of four (4) communities (Agbowa, Sagamu, Igodo and O delemo). The choice of the communities was because of the predominant farming of kola nut in the areas. And the second Stage comprised the simple random selection of 25 kola nut farmers from each community making a total of 100 kola nut farmers from 4 communities in the study area

\section{Data Analytical Techniques}

Descript statistics; multiple regression and budgetary analysis were carried out on the retrieved questionnaire from the respondents. D escriptive statistics was used to analyze and compare the socio-economic characteristics of the kola nut farmers in the study area. These include age, sex, educational status, years of kola nut farming experience, family size, marital status etc. these was presented in form of frequency tables, percentages, means, and standard deviations.

Regression Analysis was used to identify the socio-economic factors influencing the output of kola nut farmers' production in the study area. The regression model is empirically and implicitly represented as follows:

$Y=f\left(X_{1}, X_{2}, X_{3}, X_{4}, X_{5}, X_{6}, X_{7}, X_{8}, X_{9}, X_{10}, u_{i}\right)$

Where,

$\mathrm{Y}=$ output (dependent variable)

$\mathrm{X}=$ socio economic factors (the independent variables)

$\mathrm{U}=$ error term

The independent variables (socio economic factors) that are to be considered are:

$\mathrm{X}_{1}=$ Age of farmers (years) 
$\mathrm{X}_{2}=$ Farming Experience (years)

$\mathrm{X}_{3}=$ Educational level

$\mathrm{X}_{4}=$ Size of plantation (ha)

$\mathrm{X}_{5}=$ Family size

$\mathrm{X}_{6}=$ Marital status

$\mathrm{X}_{7}=$ Average age of kola nut plantation

(yrs)

$\mathrm{X}_{8}=$ Cost of labour for weeding $(\mathrm{N})$

$\mathrm{X}_{9}=$ Cost of labour for harvesting $(\mathrm{N})$

$\mathrm{X}_{10}=$ Cost of labour for processing $(\mathrm{N})$

In estimating the model, the following functional forms were also tried, linear model; semi-log; double log and Quadratic models.\#

\section{Linear Model:}

$\mathrm{Y}=\mathrm{b}_{0}+\mathrm{b}_{1} \mathrm{X}_{1}+\mathrm{b}_{2} \mathrm{X}_{2}+\mathrm{b}_{3} \mathrm{X}_{3}+\mathrm{b}_{4} \mathrm{X}_{4}+$

$\mathrm{b}_{5} \mathrm{X}_{5}+\mathrm{b}_{6} \mathrm{X}_{6}+\mathrm{b}_{7} \mathrm{X}_{7}$ $+\mathrm{b}_{8} \mathrm{X}_{8}+\mathrm{b}_{9} \mathrm{X}_{9}+\mathrm{b}_{10} \mathrm{X}_{10}+\mathrm{b}_{11} \mathrm{X}_{11}+\mathrm{U}$.

\section{Quadratic:}

$\mathrm{Y}=\mathrm{b}_{0}+\mathrm{b}_{1} \mathrm{X}+\mathrm{b}_{2} \mathrm{X}^{2}+\mathrm{b}_{3} \mathrm{X}^{2}+\mathrm{b}_{4} \mathrm{X}^{2}+\mathrm{b}_{5} \mathrm{X}^{2}$ $+b_{6} X^{2}+b_{7} X^{2}+b_{8} X^{2}+b_{9} X^{2}+b_{10} X^{2}+b_{11} X^{2}+$ $\mathrm{U}$

\section{Semi-log:}

$\mathrm{Y}=\mathrm{b}_{0}+\mathrm{b}_{1} \log \mathrm{X}_{1}+\mathrm{b}_{2} \log \mathrm{X}_{2}+\mathrm{b}_{3} \log \mathrm{X}_{3}+$ $\mathrm{b}_{4} \log \mathrm{X}_{4}+\mathrm{b}_{5} \log \mathrm{X}_{5}+\mathrm{b}_{6} \log \mathrm{X}_{6}+\mathrm{b}_{7} \log \mathrm{X}_{7}+$ $\mathrm{b}_{8} \log \mathrm{X}_{8}+\mathrm{b}_{9} \log \mathrm{X}_{9}+\mathrm{b}_{10} \log \mathrm{X}_{10}+$ $\mathrm{b}_{11} \log \mathrm{X}_{11}+\mathrm{U}$

\section{Double-log:}

$\log \mathrm{Y}=\mathrm{b}_{0}+\mathrm{b}_{1} \log \mathrm{X}_{1}+\mathrm{b}_{2} \log \mathrm{X}_{2}+\mathrm{b}_{3} \log \mathrm{X}_{3}+$ $\mathrm{b}_{4} \log \mathrm{X}_{4}+\mathrm{b}_{5} \log \mathrm{X}_{5}+\mathrm{b}_{6} \log \mathrm{X}_{6}+\mathrm{b}_{7} \log \mathrm{X}_{7}+$ b8logX 8+b9logX 9+b10logX 10+b11 logX 1 $1+\mathrm{U}$

\section{Budgetary Analysis}

It was used to determine the net farm income and the profit obtained in study area thus:

$\mathrm{GM}=\mathrm{TR}-\mathrm{TVC}$

Expense structure ratio $=\mathrm{TFC} / \mathrm{TC}$

Gross ratio $=\mathrm{TC} / \mathrm{TR}$

$\mathrm{NFI}$ is net farm income
TFI is total farm income

TFE is total farm expenses.

$\mathrm{GM}$ is gross margin

TVC is total variable cost

\section{RESULTS AND DISCUSSION OF FINDINGS}

Socio-Economic Charactenistics of the Kola nut Farmers

The knowledge of the socio-economic characteristics such as age, marital status, household size, educational level, sex etc is necessary as it provides the much needed frame work for the discussion of the results and the recommendation of the study.

\section{Age Distribution of Sampled Farmers}

Table 1 below shows that 39\% of the respondents were between the ages of 51 and 60 years, while $26 \%$ were between 61 and 70 years, they both make $65 \%$ of the total. $3 \%$ of the respondents were between 81 and 90 years with only $4 \%$ between 31 and 40 years. The remaining $10 \%$ consists of farmers between ages 71 and 80 years of age. The implication of this is that majority of the farmers are old; 78\% fall between ages 50 and 90 years. This implies that the ability to perform farm activities will be very limited in this group. Risk taking and adoption of new innovations and knowledge will be greatly limited. This is evident in the rate of adoption of improved technologies.

\section{Distribution of Respondents by Sex}

The table 2 below shows that majority of the respondents were male with 82.0 percent while few of the producers were female with 18.0 percent. This show that the male play major role in the production of kola nuts while the female take part in post harvest gathering, processing and marketing. 


\section{Table 1: Distribution of Kola nut Farmers by Age}

\begin{tabular}{llll}
\hline Age & Frequency & Percent & Cumulative \% \\
\hline $31-40$ & 4 & 4.0 & 4.0 \\
$41-50$ & 18 & 18.0 & 22.0 \\
$51-60$ & 39 & 39.0 & 61.0 \\
$61-70$ & 26 & 26.0 & 87.0 \\
$71-80$ & 10 & 10.0 & 97.0 \\
$81-90$ & 3 & 3.0 & 100.0 \\
Total & 100 & 100.0 & \\
& & & \\
\hline
\end{tabular}

Source: Field survey, 2015

Table 2: Distribution of Respondents by Sex

\begin{tabular}{llll}
\hline Sex & Frequency & Percentage & Cumulative \% \\
\hline Male & 82 & 82 & 82.0 \\
Female & 18 & 18.0 & 100 \\
Total & 100 & 100 & \\
\hline
\end{tabular}

Source: Field survey, 2015

Distribution of Farmers According To above and not less dedicated to the propaga-

\section{Farm Size}

Table 4 shows that $43 \%$ of the farmers cultivate between 2 and 2.9ha of the land while the lowest i.e. $1 \%$ of the farmers cultivate 5ha and above. Plantation is said to be an expanse of land ranging from 5 ha and tion of tree crops of economic value. When viewed against the background that plantation farming is most beneficial when a large farm size is cultivated, one can conclude that this is not a healthy situation for kola nut production business.

Table 4: Distribution of Respondents according to farm size

\begin{tabular}{llll}
\hline Size(Ha) & Frequency & Percentage & Cumulative \% \\
\hline $1-1.9$ & 17 & 17.0 & 17.0 \\
$2-2.9$ & 43 & 43.0 & 60.0 \\
$3-3.9$ & 30 & 30.0 & 90.0 \\
$4-4.9$ & 9 & 9.0 & 99.0 \\
$\geq 5$ & 1 & 1.0 & 100.0 \\
Total & 100 & 100.0 &
\end{tabular}

\section{Source: Field survey, 2015}




\begin{abstract}
Distribution of Farmers According To Distribution According To Marital Status Level of Education of Respondents

Table 5 below shows that 33\% of the respondents did not attend any school, 38\% had primary school education and $27 \%$ attended secondary school while just $2 \%$ of the respondents attended tertiary institution. The overall percentage of respondents who attended one school or the other is $67 \%$ which shows that educational level among the respondents is above average.

This implies that farmers are likely to exposed and open to accepting innovative ideas, this however is not evident in the failure of the farmers to employ improved technology like fertilizers, pesticides and ramets; with none of the respondents using at least of these items.

Table 6 below shows that $83 \%$ of the respondents are married while $1 \%$ is divorced and the other $16 \%$ are widowed.

\section{Distribution of Farmers According To Household Size}

Table 7 shows that $30 \%$ of the farmers have less than 5 members in their household. 55\% have between 5 and 8 members, 13\% have between 9 and 12 members while $2 \%$ have between 13 and 16 household size. If these members are available for kolanut production activities, there would be reduced expenditure on hired labour. When the old age of the farmers is considered, the availability of family labour is a welcome development.
\end{abstract}

Table 5: Distribution of Respondents according to their level of education

\begin{tabular}{llll}
\hline $\begin{array}{l}\text { Educational } \\
\text { Eevel }\end{array}$ & Frequency & Percentage & Cumulative \% \\
Primary school & 38 & 38.0 & 38.0 \\
Secondary school & 27 & 27.0 & 65.0 \\
Tertiary Institution & 2 & 2.0 & 67.0 \\
No Formal Educa- & 33 & 33.0 & 100.0 \\
tion & & 100.0 & \\
Total & 100 & & \\
\hline
\end{tabular}

Source: Field survey, 2015

Table 6: Distribution According To Marital Status of Respondents

\begin{tabular}{llll}
\hline Status & Frequency & Percentage & Cumulative \% \\
Married & 83 & 83.0 & 83.0 \\
Widowed & 16 & 16.0 & 99.0 \\
Divorced & 1 & 1.0 & 100.0 \\
Total & 100 & 100.0 & \\
\hline
\end{tabular}

Source: Field survey, 2015 
AN ANALYSIS OF YIELDS OF KO LA-NUT PRODUCTION, PROCESSING AND ..

Table 7: Distribution of respondents according to household size

\begin{tabular}{llll}
\hline Range(No) & Frequency & Percentage & Cumulative \% \\
\hline $1-4$ & 30 & 30.0 & 30.0 \\
$5-8$ & 55 & 55.0 & 85.0 \\
$9-12$ & 13 & 13.0 & 98.0 \\
$13-16$ & 2 & 2.0 & 100.0 \\
Total & 100 & 100.0 & \\
\hline
\end{tabular}

Source: Field survey, 2015

\section{Distribution of Farmers According To Use of Improved Technology}

Investigation shows that no farmer employed the use of any of the above listed improved technology items. Respondents prefer the use of old or traditional method of production which is evident in the use of seedling over ramets. The result agrees with the argument of Akinyosoye (1985) that most of the kola trees now growing in West Africa were raised through ICA although cuttings (Ramet) are better .This implies a low yield from the kolanut plantations and an underutilization of available technology however this may be a result of old age of majority of the farmers as well as illiteracy of the part of some of the respondents.

\section{Descriptive Statistics}

Identification of the marketing channels

Table 8 below highlights the different channels of distribution of kola nut in the study area. 37percent of the farmers sold at the farm gate to processors who engage in the processing and grading of the nut before selling to either the wholesalers, retailers or directly to the consumers. 10 percent, 12 percent, and 50 percent sold their produce to the retailers and wholesalers respectively. This means that the farmers engaged in value addition activities such as processing, sorting and grading before selling.

\section{Budgetary Analysis}

Table 9 below shows the minimum and maximum total variable cost (TVC) such as the cost of labour for processing, cost of labour for harvesting, cost of labour for weeding, cost incurred on kola nut transportation of the respondents to be N17,800 and N129,420 respectively with the mean variable cost as N53359.50.The minimum and maximum total fixed cost (TFC) which includes the cost of cutlass, basket, files and hoes for all the kolanut farmers are N11,600 and N61,150 respectively with a mean of $N$ 29109.10.These implies that the farmer that spent the least on variable inputs spent $\mathrm{N} 17,800$ per hectare and the farmer that spent the highest on variable inputs spent N129,420 per hectare. Also, the farmer that spent the least on fixed inputs spent $\mathrm{N}$ 11,600 per hectare and the famer that spent the highest spent N 61,150 per hectare.

Table 9 also shows the net farm income (Total farm income- Total farm expenses or the Total revenue- Total cost) having its minimum as $\mathrm{N}-11,800$, maximum as N701,350 and mean as N208,680.40 per hectare. This explains that the minimum net farm income of the farmers is negative with a loss of 11,800 (meaning that not all farmers made profit maybe due to the fact that they fail to engage in value addition activities such as processing, sorting and grading) and the maximum net farm income i.e. profit for ko- 
lanut production amongst the respondent to be N701,350. The Gross margin (Total Revenue-Total variable cost) was also shown to have a minimum value of $\mathrm{N}$ 6,000, maximum of $\mathrm{N} 737,700$ and a mean of N237789.50 per hectare which shows that kolanut production and marketing is a profitable venture.

The table shows the Gross ratio (Total cost/ Total Revenue) to be 0 (minimum), 1 (maximum) and mean of 0.36 . This means that at the minimum value the farmer in- curred no cost during production and at the maximum value, the farmers operated at a break-even point (No profit, no loss). The table also shows Expense structure ratio (TFC/ TC) which is the proportion of the total cost that was spent on the total fixed cost to be 0 (minimum), 1 (maximum) and a mean of 0.36 . This means that the proportion of total cost spent on total fixed cost for minimum was zero and all the proportion of total cost was spent on total fixed cost for the maximum.

Table 8: Identification by whom the farmer sells to

\begin{tabular}{llll}
\hline & Frequency & Percentage & Cummulative \\
\hline Processors & 37 & 37.0 & 37.0 \\
Retailers & 12 & 12.0 & 49.0 \\
Wholesalers & 50 & 50.0 & 99.0 \\
Consumer & 1 & 1.0 & 100 \\
Total & 100 & 100 & \\
\hline
\end{tabular}

Table 9: Budgetary Analysis Table

\begin{tabular}{lcccc}
\hline & n & minimum & maximum & mean \\
\hline TVC & 100 & 17800 & 129420 & 53359.50 \\
TFC & 100 & 11600 & 61150 & 29109.10 \\
REVENUE & 100 & 45000 & 812500 & 291149.00 \\
TOTAL CO ST & 100 & 35400 & 190570 & 82468.60 \\
NET FARM INCOME & 100 & -11800 & 701350 & 208680.40 \\
GROSS.MARG IN & 100 & 6000 & 737700 & 237789.50 \\
ESR & 100 & 0 & 1 & 0.36 \\
GROSS RATIO & 100 & 0 & 1 & 0.36 \\
\hline
\end{tabular}


AN ANALYSIS OF YIELDS OF KO LA-NUT PRODUCTION, PROCE SSING AND ..

\section{Multiple Regressions}

The lead equation that best fit the research work is cob-douglas or double log function based on the highest number of significant variables and higher F-value. From the lead equation, the analysis showed the coefficient of determination (R-square) as 0.554 . This explains that 55.4 percent of the variation in the output $(\mathrm{kg})$ of kolanut is explained by the regressors. This further explains that the significant independent variables can reliably predict the 55.4 percent variability of the dependent variable $(\mathrm{Y})$.

There were three variables that are signifi- cant at $10 \%, 5 \%$ and $1 \%$. These variables are age of the farmers, farming experience and farm size. The age of farmers $\left(\mathrm{x}_{1}\right)$ was negatively significant which implies that as farmers reach old age, this may serve as hindrance due to physical inability to undertake vigorous farm activities hence reduction in output occurs by $13.3 \%$. Farming experience $\left(\mathrm{x}_{2}\right)$ was negatively correlated with output of kolanut indicating that a unit increase in experience of kolanut farmers will decrease output by $12.3 \%$. Farm size was found to positively significant which implies that a unit increase in farm size will increase output by $83.1 \%$.

Table 10: Multiple Regression Analysis of kola nut producers in the study area

\begin{tabular}{lrrrrrrrrr}
\hline & $\mathbf{b}_{\mathbf{0}}$ & $\mathbf{b}_{\mathbf{1}}$ & $\mathbf{b}_{\mathbf{2}}$ & $\mathbf{b}_{\mathbf{3}}$ & $\mathbf{b}_{\mathbf{4}}$ & $\mathbf{b}_{\mathbf{5}}$ & $\mathbf{b}_{\mathbf{6}}$ & $\mathbf{R}^{2}$ & $\mathbf{F}$ \\
\hline linear & & \multicolumn{7}{c}{${ }^{* * *}$} & ${ }^{* *}$ \\
& 3.44 & -0.75 & 0.38 & -1.17 & 4.00 & 2.06 & -0.47 & 0.777 & 5.71 \\
& $*$ & $* *$ & & $* * *$ & & & & \\
double log & 9.80 & -1.67 & -2.54 & 1.03 & 7.15 & 0.61 & -0.645 & 0.554 & 11.01 \\
\hline
\end{tabular}

* Significant at $10 \% * *$ Significant at $5 \%$

\section{CONCLUSION}

The results of the farm budgeting analysis showed the average gross margin as N237,789.50 showing that the business is profitable depending on level of experience and farm size. The average net farm income was also shown as $\mathrm{N} 208,680.40$. From the regression analysis, the age of farmers $\left(\mathrm{x}_{1}\right)$ was negatively significant which implies that as farmers reach old age, this may serve as hindrance due to physical inability to undertake vigorous farm activities hence reduction in output occurs by $13.3 \%$. Farming
*** Significant at $1 \%$

experience $\left(\mathrm{x}_{2}\right)$ was negatively correlated with output of kolanut indicating that a unit increase in experience of kolanut farmers will decrease output by $12.3 \%$. Farm size was found to positively significant which implies that a unit increase in farm size will increase output by $83.1 \%$. Kola nut production is a profitable business as deduced from the scope of this study. It is a good source of income generation both for the farmers, marketers and even the government through internal sales and export; it also provides employment opportunities and supplies raw 
materials for industries. However, there were certain observations made which serves as constraints in increasing kola nut output. These include reliance on only traditional knowledge of planting, difficulties procuring loans and transportation problems.

\section{RECOMENDATIONS}

The result and findings of this research is an eye opener to opportunities and potentials in kola nut business. However, in order to unleash this opportunities and improve the productivity of kola nut in the study area, the following are recommendations for producers, government and other institutions concerned;

\section{Producers}

- Kola nut farmers should engage in value addition activities such as processing and sorting of kola nut before selling so as to increase their income.

- Kola nut farmers should attempt the use of improved technologies in order to improve productivity.

- They should form themselves into association in order to get easy access to Agricultural institutions for help through sectors such as Agricultural Media Resources and Extension Centre (AMREC) an extension arm of the Federal University of Agriculture, Abeokuta.

- Women should be encouraged to engage in kola nut business in order to generate additional income to improve their livelihood.

\section{Govemment}

- Government should provide avenue for awareness creation on the im- portance of improved technology for kola nut farmers through solid extension programmes on kola nut.

- Should ensure that various technological inputs such as fertilizers, Ramets, pesticides, tractors etc that can enhance production and productivity are made available to kola nut farmers at subsidized rate.

- Granting loans is another area that the government can assist the farmers as funding remains one of the notable factors facing them.

- Government should address the issue of transportation.

\section{REFERENCES}

Adebayo A.A (1966). Kda diseses Ann. Rept. Cocoa Research Institute of Nigeria,127-130.

Adebowale L. A. and 0 desanya B. 0 (2015). Effects of kola cultivation on soil fertility status of selected kolanut plantations in Ogun State, Western Nigeria. International Research Journal of Agricultural Science and Soil Science 5(5)129-136.

Adejompo F (2014). The Impact of Kolanut Production on the Economy of Akoko South West Local G overnment, O ndo State, Nigeria. Bitish Jaumal of Humanities and Social Sáenes 11 (2): pages.

\section{Agbeniyi, S.0, and Fawole B (1999).}

Effects of curing and pre-storage die treatments on mould of kolanuts. Eur. J. FoodRes. Technd., 208: 447-449.

Agbeniyi , S.O, Otuonye, A.H, and Adedeji, A.R (2000). Mycoflora Associated with Post Harvest Processing stages of kolanuts ( Cda nitida vent Schatt and Endider). J. FoodTehmd. Afr., 5(4): 129-131. 
Aiboni V. U and Ogunkunle A. 0 Nigria Res. Bull. CRIN, Ibadan, 3: 33.

(1988). An index of soil productivity for cassava and yam on the basement complex soil in south western Nigeria. J. of SaenceResearch, 4(1);77-85.

Moloney, A. (1887). Sketch of the Forestry of West Africa. Sampson Low, London.

National survey on Agricultural Exportable Commodities (2013). 31.

Akinbode A. A (1982). Kolanut production and trade in Nigeria. NISER Publication, $\mathrm{p}$ 1-22.

Alademerin, E. A. and 0 dusina, 0. A. (2009). Land Use in Agriculture. Royal Link Press, Ogun State, Nigeria In K. M. Makinde, A. O. Ayegbokiki, \& O. A. Sotunde (2013). Accounting for employment generation and expansion: A tool for insecurity in Nigeria. African Jaumal of Business Management. 7(31): 3063-3068.

Asogwa E.U., Mokwunye F.C., Otuonye A.H., Oluyole K.A., Ndubwku T.C.N and Uwagboe E.0 (2011).Kolanut production, processing and marketing in the south eastern states of Nigeria, African Jarnal of pant sienee 5(10): 547-551

Babatunde, B.B, and Hamzat, R.A (2005). Effects of feeding graded levels of kolanut husk meal on the performance of cockrels. Nigerian Jaumal on Animal Pro duction 32(1): 61-66.

Beattie G. B (1970). Soft drink flavours: Their history and characteristics. 1: Cola for kola flavours. The Flavour Industry. 390 394.

Central Bank of Nigeria, and Nigeria Institute of Social and Economics Research (1992). The Impact of S.A.P on the Nigeria Agricultural and Rural Life CBN/ NISER National Studies.

.N dagi, F.D., Babalola, I. U., Mokwunye, C. F., Anagbogu, I. A., Aderolu, 0., Ugiom, E. U.,Asogwa, M., Idrisu, and Mokwunye F. C. (2012). Potentials and Challenges of Kolanut Production in Niger State, Nigeria. International Scholarly Research Network

Obeng E.T, and Brown N. (2001). Cola nitida and Cola acuminata. A State of Knowledge Report undertaken for The Central African Regional Program for the Environment. Oxford Forestry Institute D epartment of Plant Sciences University of $\mathrm{Ox}$ ford United Kingdom.

Oladokun M. A. 0. (2000). "O bjectives and achievements in Kola propagation. Research paper presented at a symposium to mark the 21st Anniversary of the Establishment of CRIN,"

Olunloyo, 0. A. (1979). Fungi associated with deterioration of stored kola nuts. Nige nan Jaumal of Agiaultural Saiences, 1: 51-59. Opeke, L. K. (1992). Tropical tre arps Spectrum Books Ltd., Ibadan.

Odebode A. C, and Olunloyo OA (1989). Important diseases of kola: In Progess in Tree Crop Research A commemorative book to mark the 25th anniversary of Cocoa Research Institute of Nigeria, Ibadan, Nigeria. 111-114.

Oguntuga, D.B.A. (1975). Chemical composition and potential commercial uses of Daramola, A.M (1978). Inseet Pests of cola in kola nuts, Cola nitida (Vent) Schoot 
E. O. A. OLUWALANA, , L. O. OKOJIE, F. O ASHAOLU AND V. O.OLANIRAN

and Endlicher. Ghana J. Agic Sa., 8: 121- 32, 210-240.

125.

Purseglove, J. W. (1968). Trqpical acps Di-

Russell, T. A. (1955). Thekda of Nigria and cetyleetons Longmans G reen and Co Ltd, LontheCameoons Tropical Agriculture, Trinidad don.

(Manuscipt receiveet 17thFebnary, 2017; accepted 20thJune, 2017 